\title{
Therapeutic Effects of Lignans and Blend Isolated from Schisandra chinesis on Hepatic Carcinoma
}

\author{
Dae Youn Hwang \\ Pusan National University, \\ Republic of Korea
}

\section{Introduction}

Schisandra chinesis (S. chinesis) is widely used as one of the 50 fundamental herbs in traditional Oriental medicine; the species is a member of the Schisandra genus of shrub, which grows commonly in the native forests of Northern China, Korea, Japan and Russia. The Schisandra are deciduous climbers that thrive in any type of soil, so long as it is moist, shaded, and well-drained (Panossian and Wikman, 2008). The female S. chinesis plant can produce the fruit via fertilization with pollen from a male plant (Shilova, 1963). It is harvested in most countries, including Korea, by the cutting of half-matured berries between August and September. The berries of S. chinesis are called omija (translated as "five-flavor fruit") in Korea, because this fruit has all five of the basic flavors-salty, sweet, sour, pungent, and bitter (Gutnikova, 1951; Panossian and Wikman, 2008). Generally, its dried fruits have been used for a variety of purposes, including as a therapeutic drug, teas and wines. In many countries, it has been used as a therapeutic drug, and is purported to have liver-protective and immune-modulatory abilities. A variety of key constituents including schizandrin, deoxyschizandrin, gomisin, and pregomisin have been isolated from the seeds of the fruit. Additionally, S. chinesis berries have been used in the manufacture of several foods. A wine was using the berries of $S$. chinesis has been produced in China, whereas in Korea, the berries are made into a tea. Meanwhile, in Japan, these berries are referred to as "gomishin", and have been used for medicinal purposes, to treat colds and sea-sickness. In Russia, dozens of tons of berries are used annually in the commercial production of juices, wine, extracts and sweets (Gutnikova, 1951; Agejenko and Komisssarenko, 1960).

A variety of previous pharmacological studies have suggested that $S$. chinesis may exert beneficial biological effects on liver tissue, the central nervous system, the respiratory system, the cardiovascular system and the endocrine system (Table 1) (Panossian and Wikman, 2008). The major and characteristic components of Schisandraceae berries have been previously isolated, and are referred to as lignans. The lignans are categorized into the five following classes: dibenzocyclooctadiene lignans (type A), spirobenzofuranoid dibenzocyclooctadiene lignans (type B), 4-aryltetralin lignans (type C), 2,3-dimethyl-1,4diarylbutane lignans (type D), and 2,5-diaryltetrahydrofuran lignans (type E)(Table 2)(Lu and Chen, 2009). Thus far, a total of 43 lignans have been isolated from $S$. chinesis in various 
studies; a list is provided in Table 2. Among these lignans, most of the lignans isolated from S. chinesis exhibit a dibenzocyclooctadiene lignan (type A) structure, with the exception of three lignans: pregomisin, meso-dihydroguaiaretic acid and nordihydroguaiaretic acid. The three lignans described in this chapter are of the type A structural group. Additionally, the dibenzocyclooctadiene lignans are further divided into two types based on their stereostructures-S- and R-biphenyl configuration. Structural elucidation studies have shown that the cyclooctene rings of dibenzocyclooctadiene lignans evidence a twist-boat-chair (TBC) or twist-boat (TB) conformation ( $\mathrm{Lu}$ and Chen, 2009). Approximately half of the lignans from $S$. chinesis evidence an S-biphenyl configuration and the other half exhibit an Rbiphenyl configuration. According to the conformation with cyclooctene rings, only four lignans exhibited a TB conformation, but the rest of the lignans had the TBC conformation. Among the three lignins described in this chapter, only gomisin $\mathrm{N}$ exhibits an S-biphenyl configuration, whereas tigloylgomisin $\mathrm{H}$ and schisandrin $\mathrm{A}$ has an R-biphenyl configuration.

\begin{tabular}{|l|l|l|}
\hline Body system & $\begin{array}{l}\text { Regulatory system: stress- } \\
\text { system }\end{array}$ & $\begin{array}{l}\text { Pharmacological effect: adaptogenic } \\
\text { effect }\end{array}$ \\
\hline $\begin{array}{l}\text { Cardiovascular } \\
\text { system }\end{array}$ & $\begin{array}{l}\text { Central and vegetative } \\
\text { nervous system }\end{array}$ & Stimulating effect \\
\hline $\begin{array}{l}\text { Gastrointestinal } \\
\text { system }\end{array}$ & Endocrine system & $\begin{array}{l}\text { Stress-mimetic and stress-protective } \\
\text { effect }\end{array}$ \\
\hline Respiratory system & Immune system & Stress-protective effect \\
\hline
\end{tabular}

Table 1. Summary of the pharmacological activities of S. chinensis (Panossian and Wikman, 2008).

\begin{tabular}{|c|c|c|c|}
\hline Compounds & $\begin{array}{c}\text { Structure } \\
\text { type }\end{array}$ & $\begin{array}{l}\text { Configuration/ } \\
\text { conformation }\end{array}$ & References \\
\hline Gomisin N & $\mathrm{A}$ & $\mathrm{S} / \mathrm{TBC}$ & Ikeya et al., 1978a \\
\hline $\begin{array}{c}\text { Schizandrin } \mathrm{C} \text { (wuweizisu } \mathrm{C} \text {, } \\
\text { schisandrin } \mathrm{C})\end{array}$ & A & S/TBC & Chen and Shu, 1976 \\
\hline$(-)$-Gomisin K1 & $\mathrm{A}$ & S/TBC & Ikeya et al., 1980 \\
\hline Gomisin J & $\mathrm{A}$ & S/TBC & Ikeya et al., 1978b \\
\hline (-)-Gomisin L2 & $\mathrm{A}$ & S/TBC & Ikeya et al., 1982 \\
\hline (-)-Gomisin L1 & A & $\mathrm{S} / \mathrm{TBC}$ & Ikeya et al., 1982 \\
\hline Gomisin S & A & S/TBC & Ikeya et al., 1988 \\
\hline Epigomisin $\mathrm{O}$ & A & S/TBC & $\begin{array}{l}\text { Ikeya et al., 1991; } \\
\text { Ikeya et al., 1979 }\end{array}$ \\
\hline Tigloylgomisin $\mathrm{P}$ & A & S/TBC & $\begin{array}{l}\text { Ikeya et al., 1990; } \\
\text { Ikeya et al., 1980 }\end{array}$ \\
\hline Angeloylgomisin $\mathrm{P}$ & A & S/TBC & $\begin{array}{l}\text { Ikeya et al., 1990; } \\
\text { Ikeya et al., 1980 }\end{array}$ \\
\hline Gomisin D & A & S/TBC & Ikeya et al., 1976 \\
\hline Gomisin E & $\mathrm{A}$ & S/TBC & Ikeya et al., 1979 \\
\hline Gomisin $\mathrm{O}$ & $\mathrm{A}$ & S/TBC & Ikeya et al., 1979 \\
\hline 6-o-benzoylgomisin $\mathrm{O}$ & $\mathrm{A}$ & S/TB & Chen et al., 1994 \\
\hline Angeloylgomisin $\mathrm{O}$ & A & $\mathrm{S} / \mathrm{TB}$ & Ikeya et al., 1982 \\
\hline
\end{tabular}




\begin{tabular}{|c|c|c|c|}
\hline Angeloyl isogomisin $\mathrm{O}$ & $\mathrm{A}$ & S/TB & Ikeya et al., 1982 \\
\hline Benzoyl isogomisian $\mathrm{O}$ & A & S/TB & Ikeya et al., 1982 \\
\hline Schisandrene & A & $\mathrm{S} / \mathrm{TBC}$ & Choi et al., 2006 \\
\hline Angeloylgomisin Q & $\mathrm{A}$ & $\mathrm{S} / \mathrm{TBC}$ & Ikeya et al., 1979 \\
\hline Gomisin F & A & S/TBC & Taguchi and Ikeya, 1977 \\
\hline Gomisin G & $\mathrm{A}$ & S/TBC & Taguchi and Ikeya, 1977 \\
\hline $\begin{array}{c}\text { Schisantherin A(gomisin C, } \\
\text { wuweizi ester A) }\end{array}$ & A & $\mathrm{S} / \mathrm{TBC}$ & $\begin{array}{c}\text { Ikeya et al., 1990; } \\
\text { Taguchi and Ikeya, } 1977\end{array}$ \\
\hline $\begin{array}{c}\text { Schisantherin B(gomisin B, } \\
\text { wuweizi ester B) }\end{array}$ & A & $\mathrm{S} / \mathrm{TBC}$ & $\begin{array}{c}\text { Ikeya et al., 1990; } \\
\text { Taguchi and Ikeya, } 1977\end{array}$ \\
\hline Schisantherin D & A & $\mathrm{S} / \mathrm{TBC}$ & $\begin{array}{l}\text { Liu et al., 1978; } \\
\text { Ikeya et al., } 1982\end{array}$ \\
\hline Gomisin R & $\mathrm{A}$ & S/TB & Ikeya et al., 1982 \\
\hline $\begin{array}{c}\text { Deoxyschizandrin } \\
\text { (wuweizisu A, schisandrin A, } \\
\text { deoxyschisandrin) }\end{array}$ & A & $\mathrm{R} / \mathrm{TBC}$ & $\begin{array}{l}\text { Chen and Shu, 1976; } \\
\text { Yue et al., } 1994\end{array}$ \\
\hline$(+)$-Gomisin K2 & $\mathrm{A}$ & $\mathrm{R} / \mathrm{TBC}$ & Ikeya et al., 1980 \\
\hline Schisanhenol [(+)-gomisin K3] & $\mathrm{A}$ & $\mathrm{R} / \mathrm{TBC}$ & $\begin{array}{l}\text { Ikeya et al., 1980; } \\
\text { Ikeya et al., } 1990\end{array}$ \\
\hline$\gamma$-Schizandrin $(\gamma$-schisandrin $)$ & $\mathrm{A}$ & $\mathrm{R} / \mathrm{TBC}$ & Liu et al., 1978 \\
\hline $\begin{array}{l}\text { Schizandrin } \mathrm{B}(\text { wuweizisu } \mathrm{B}, \\
\text { schisandrin } \mathrm{B},( \pm)-\mathrm{Y}^{-} \\
\text {schizandrin) }\end{array}$ & A & $\mathrm{R} / \mathrm{TBC}$ & Chen and Shu, 1976 \\
\hline$( \pm)$-Gomisin M1 & A & $\mathrm{R} / \mathrm{TBC}$ & Ikeya et al., 1982 \\
\hline$(+)$-Gomisin M2 & $\mathrm{A}$ & $\mathrm{R} / \mathrm{TBC}$ & Ikeya et al., 1982 \\
\hline $\begin{array}{c}\text { Schizandrin(schisandrol A, } \\
\text { schisandrin, wuweizi alcohol A) }\end{array}$ & A & $\mathrm{R} / \mathrm{TBC}$ & Chen and Shu, 1976 \\
\hline $\begin{array}{c}\text { Gomisin A(schisandrol B, } \\
\text { wuweizi alcohol B) }\end{array}$ & $\mathrm{A}$ & $\mathrm{R} / \mathrm{TBC}$ & Taguchi and Ikeya, 1977 \\
\hline Gomisin $\mathrm{H}$ & A & $\mathrm{R} / \mathrm{TBC}$ & Ikeya et al., 1979 \\
\hline Angeloylgomisin $\mathrm{H}$ & $\mathrm{A}$ & $\mathrm{R} / \mathrm{TBC}$ & Ikeya et al., 1979 \\
\hline Tigloylgomisin $\mathrm{H}$ & $\mathrm{A}$ & $\mathrm{R} / \mathrm{TBC}$ & Ikeya et al., 1979 \\
\hline Benzoylgomisin $\mathrm{H}$ & A & $\mathrm{R} / \mathrm{TBC}$ & Ikeya et al., 1979 \\
\hline Gomisin T & $\mathrm{A}$ & $\mathrm{R} / \mathrm{TBC}$ & Ikeya et al., 1988 \\
\hline Isoschizandrin & $\mathrm{A}$ & $\mathrm{R} / \mathrm{TBC}$ & $\begin{array}{r}\text { Ikeya et al., 1991; } \\
\text { Ikeya et al., } 1988\end{array}$ \\
\hline Pregomisin & $\mathrm{D}$ & / & Ikeya et al., 1978 \\
\hline Meso-dihydroguaiaretic acid & $\mathrm{D}$ & / & Ikeya et al., 1979 \\
\hline Nordihydroguaiaretic acid & $\mathrm{D}$ & 1 & Sakurai et al., 1992 \\
\hline
\end{tabular}

Table 2. Lignans isolated from the fruits of $S$. chinensis. A: Dibenzocyclooctadiene lignan; D: 2,3-dimethyl-1,4-diarylbutane lignan; $S$ or R: the configuration of the biphenyl unit; TBC or TB: the conformation of the cyclooctane ring (Lu and Chen, 2009).

Meanwhile, hepatocellular carcinoma is a primary malignancy of the hepatocytes, and generally leads to death within 6-20 months. The disease is the fifth most common cancer in men and the eighth most common cancer in women worldwide (Bosch et al., 2004). Cirrhosis of any etiology is known to be the major risk factor for hepatocellular carcinoma (Adami et al., 2008). Thus far, approximately $80 \%$ of patients with newly diagnosed 
hepatocellular carcinoma have preexisting cirrhosis in the liver organ, caused mainly by excessive alcohol use, hepatitis C infection and hepatitis B infection (El-Serang and Mason, 2000). Additionally, many therapeutic strategies have been attempted to medically treat hepatocellular carcinoma, including surgical resection and liver transplantation, although the available treatment options depend on the specific characteristics of the tumor (Thomas and Zhu, 2005; Bruix and Sherman, 2005).

There has been some very interesting research conducted to determine whether the lignans isolated from S. chinensis may improve and prevent a variety of human diseases, including cardiac disease, respiratory disease, immune disease, endocrine disease and neuronal disease. However, only a few investigations have been conducted to determine the therapeutic effects of lignans isolated from S. chinensis on hepatic carcinoma. Therefore, this chapter describes the important results of an experiment using three lignans (gomisin N, tigloylgomisin $\mathrm{H}$ (TGH) and schisandrin A) and one blend (KY88 Liver-Livo) which may prove valuable in the development of a therapeutic drug for the treatment of hepatic carcinoma.

\section{Therapeutic effects of lignans and blend isolated from S. chinensis on hepatic carcinoma}

This main section described experimental data regarding the biological effects of three lignans and a blend on hepatic carcinoma, and the potential for the use of those lignins as therapeutic drugs.

\subsection{Effects of gomisin $\mathbf{N}$}

Gomisin N (Fig. 1) is already well known as a member of the schisandrin B family, and the most abundant lignin in the fruit lignins of $S$. chinensis. Among the various functions of gomisin $\mathrm{N}$, its ability to increase antioxidant capacity and protect against mitochondria decay was initially identified by a biochemical mechanism study (Ko and Lam, 2002). Additionally, gomisin $\mathrm{N}$ could induce an increase in heat shock protein, which performed an important function when cells and tissues were affected by a variety of stressful stimuli from the external environment. Recently, a stereoisomer of gomisin N, (-) schisandrin B, was identified and its function in cell protection was investigated. These results demonstrated that schisandrin $B$ and (-) schisandrin B were the most potent in enhancing antioxidant protection. Therefore, these two lignans may be employed for the protection against and reversal of tissue damage induced by environmental hazards, physical exercise, and aging (Chiu et al., 2006). However, we found a new function of gomisin $\mathrm{N}$, particularly its effects against hepatic carcinoma.

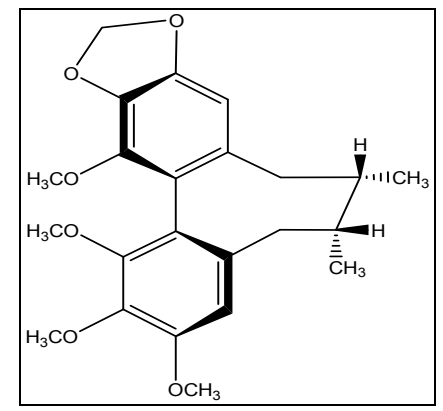

Fig. 1. Chemical structure of gomisin $\mathrm{N}$ isolated from $S$. chinensis. 


\subsubsection{Preparation of gomisin $\mathbf{N}$}

The dried fruits of $S$. chinensis $(2.5 \mathrm{~kg})$ were ground to a fine powder and were successively extracted at room temperature with $n$-hexane, EtOAc, and $\mathrm{MeOH}$. The hexane extract (308 g) was evaporated under vacuum and chromatographed on a silica gel ( $40 \mu \mathrm{m}$, J.T. Baker, NJ, USA) column $(70 \times 8.0 \mathrm{~cm})$ with a step gradient of $0 \%, 5 \%, 10 \%, 20 \%$, and $30 \%$ EtOAc in hexane (each $1 \mathrm{~L}$ ). Of these extracts, Fraction 11IA, one of 5 subfraction originated from fraction 11 was further purified by column chromatography on silical gel eluting with $\mathrm{CHCl}_{3}$-acetone (19:1) to give a gomisin $\mathrm{N}$ (774 mg)(Yim et al., 2009).

\subsubsection{Effects of gomisin $\mathrm{N}$ on cell proliferation}

The therapeutic effects of gomisin $\mathrm{N}$ on hepatic carcinomas was initially suggested by Yim et al. (2009). First, they extracted lignans including gomisin N (Seo et al., 2004), schisandrin (Ikeya et al., 1979a), schisandrin C (Seo et al., 2004) and gomisin A (Ikeya et al., 1979b; Park et al., 2007) from $S$. chinensis via $n$-hexane, EtOAc and $\mathrm{MeOH}$ extraction techniques. Their structures were analyzed via LC-MS and NMR analysis for identification. Proliferation activity was screened for all groups that had received one of the four lignans of varying concentrations via an MTT assay to select the lignan with the highest apoptotic effect on hepatic carcinoma. For schisandrin C, the MTT assay demonstrated that this lignan induced cell proliferation rather than cell death in hepatic carcinoma cells in a concentration range of $40 \mu \mathrm{M}$ to $160 \mu \mathrm{M}$, whereas the gomisin A-treated group maintained a stable cell population (Fig. 2). However, the MTT screening also demonstrated that two lignans, gomisin $\mathrm{N}$ and schisandrin, significantly induced cell death in relation to other lignans. In the gomisin Ntreated group, cell proliferation in the $40 \mu \mathrm{M}$-treated groups was slightly increased compared to the vehicle. However, cell proliferation decreased rapidly in a gomisin $\mathrm{N}$ concentration range from $80 \mu \mathrm{M}$ to $320 \mu \mathrm{M}$ (Fig. 2). Schisandrin also induced cell death at the higher concentrations, but the cell death ratio was lower than that observed with gomisin $\mathrm{N}$ (Fig. 2). These results indicated that gomisin $\mathrm{N}$ treatment was highly effective in inducing the death of hepatic carcinoma cells at higher concentrations, but not at low concentrations. Yim et al. selected gomisin $\mathrm{N}$ as the candidate lignan for further analysis, owing to its anti-proliferation and pro-apoptosis functions.

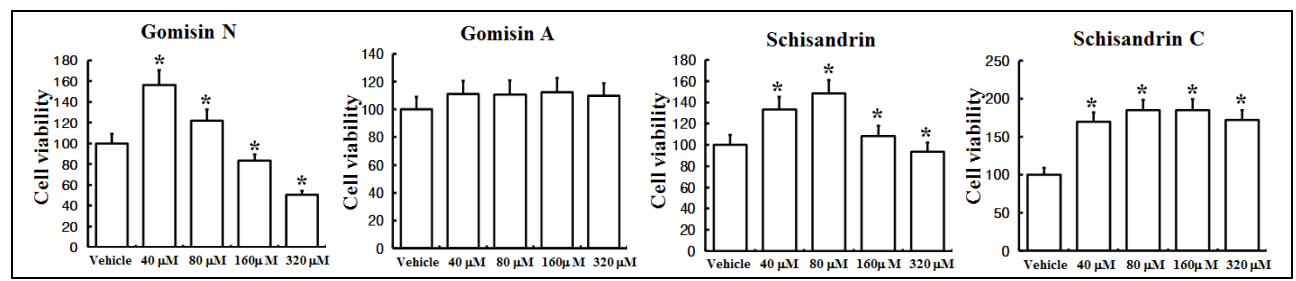

Fig. 2. Anti-proliferative effect of gomisin N, schisandrin, schisandrin C and gomisin A isolated from S. chinensis (Yim et al., 2009).

Additionally, phase-contrast microscope analysis was conducted to determine whether the cell death effects observed in the MTT assay were concurrent with the observed cell morphological changes. In the $40 \mu \mathrm{M}$-treated group, the number and morphology of hepatic carcinoma evidenced greater crowding than was observed in the vehicle-treated group. The hepatic carcinoma cell line in the $80 \mu \mathrm{M}$-treated groups evidenced a pattern similar to that observed with the vehicle-treated group. In the $160 \mu \mathrm{M}$-treated group, few dead cells were 
observed in the microscopic images of the hepatic carcinoma cell line. The numbers of these cells were increased markedly in the $320 \mu \mathrm{M}$-treated groups (Fig. 3). These results demonstrated that the results observed on cell morphology analysis under gomisin $\mathrm{N}$ treated conditions were consistent with the results of an MTT assay under the same conditions (Yim et al., 2009).
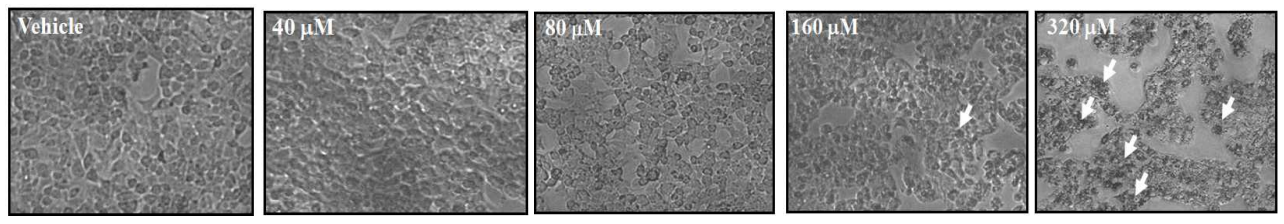

Fig. 3. Microscope images of hepatic carcinoma cell lines after $24 \mathrm{hrs}$ of treatment with gomisin $\mathrm{N}$ at various concentrations (Yim et al., 2009).

\subsubsection{Effects of gomisin $\mathbf{N}$ on apoptosis}

Apoptosis, or programmed cell death, performs a critical role in a variety of physiological processes during fetal development and in adult life. Defects in the apoptotic process lead to the progress of many diseases involving progressive cell accumulation and cancer in most cases. Yim et al. (2009) further investigated the correlation between gomisin $\mathrm{N}$ and apoptosis. To achieve this, a hepatic carcinoma cell line treated with various concentrations of gomisin $\mathrm{N}$ were stained with FITC Annexin V, and fluorescence activity was determined via flow cytometry. Gomisin N significantly induced the increase in the number of cells undergoing apoptosis, from $15 \%$ to $98 \%$, in $24 \mathrm{hrs}$. However, this reaction was induced even at low gomisin $\mathrm{N}$ concentrations, and this level of induction remained at a constant level up to and throughout higher concentrations (Fig. 4). Therefore, these results indicated that gomisin $\mathrm{N}$ could induce the apoptosis of hepatic carcinoma cell lines in a dose-independent manner. Specifically, gomisin $\mathrm{N}$ may induce the loss of plasma membrane asymmetry, one of the early events in the apoptosis process, for most cells treated at a concentration of 40 $\mu \mathrm{M}$.

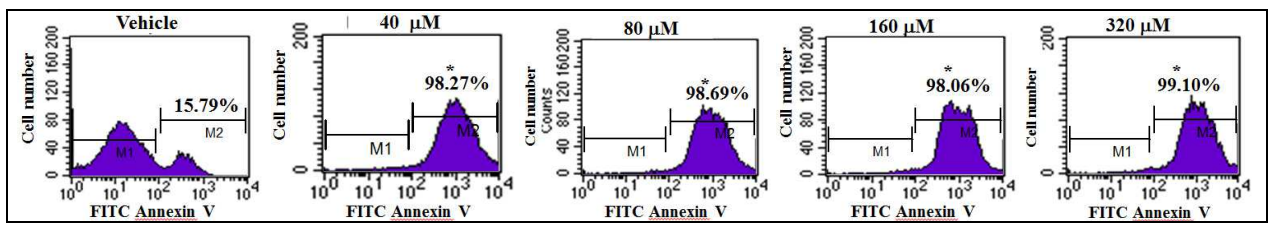

Fig. 4. Identifying apoptotic cells affected with gomisin $\mathrm{N}$ treatment. Hepatic carcinoma cells were incubated with gomisin $\mathrm{N}$ at various concentrations for $24 \mathrm{hrs}$, and stained with FITC Annexin V to detect the apoptotic cells (Yim et al., 2009).

Additionally, the apoptosis process involves many families of proteins. Among these proteins, the Bcl-2 proteins are one of the key molecules in inducing the anti-apoptotic process (Apakama et al., 1996). The results of previous studies have shown that this protein was overexpressed in many solid tumors, and that it contributes to chemotherapy resistance and radiation-induced apoptosis (Apakama et al., 1996; Joensuu et al., 1994). Unlike many other known human oncogenes, Bcl-2 exerts its influence by enhancing cell survival rather 
than by stimulating cell division (Joensuu et al., 1994). Yim et al. (2009) attempted to determine whether the expression level of Bcl-2 protein would be affected by gomisin $\mathrm{N}$ treatment in a hepatic carcinoma cell line. Additionally, Yim et al. (2009) assessed the effects of gomisin $\mathrm{N}$ treatment on proteins associated with the apoptosis signaling pathway. To achieve this, the expression levels of Bcl-2 and Bax proteins were determined in the vehicletreated and gomisin N-treated groups via Western blot analysis. The expression level of Bcl2 protein did not change in the low concentration range as compared to the vehicle. However, the high concentration range-namely the $160 \mu \mathrm{M}$ and $320 \mu \mathrm{M}$-treated groupsevidenced higher levels of $\mathrm{Bcl}-2$ protein expression than was observed in the low concentration range. In the case of Bax, the expression level of this protein was markedly increased only in the $320 \mu \mathrm{M}$ treated group compared to the vehicle and the other concentration groups. Furthermore, in order to determine whether the tumor suppressor gene would be affected by gomisin $\mathrm{N}$ in the hepatic carcinoma cell line, the expression level of p53 protein was detected in the vehicle and gomisin N-treated groups. The expression level of p53 protein remained unchanged in the four treatment groups and the vehicle (Fig. 5). These results indicate that gomisin $\mathrm{N}$ may simultaneously induce an increase in the levels of the proteins associated with the anti-apoptotic and pro-apoptotic processes, but does not alter the level of expression of the tumor suppressor protein, p53.

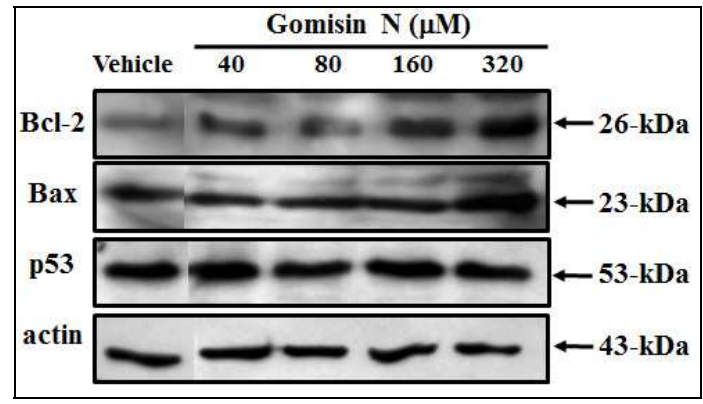

Fig. 5. Effects of gomisin $\mathrm{N}$ on Bcl-2, Bax and p53 protein expression to investigate the mechanism underlying apoptosis (Yim et al., 2009).

\subsection{Effects of KY88 liver-livo (KY88)}

KY88 was one of herbal blends containing Schizandrae fructus (Chow et al., 2001). Thus far, three major functions of this drug have been demonstrated; the modulation of the immune system, the induction of apoptosis, and the induction of cytokines by lymphocytes and liver cancer cells (Chow et al., 2004). However, a thorough determination of the therapeutic effects of KY88 against hepatic carcinoma will require further research into its action mechanism.

\subsubsection{Preparation of KY88}

KY88 is a blend containing the herbal extract of Schizandrae fructus, Bupleuri radix, Artemisiae capillaris, Desmodii herba, Poria sclerotium, Lithospermi radix, Paeoniae radix, Phellodendri cortex, Scutellariae radix and Trichosanthis radix. Ten grams of each of all ingredients of above herbs were primarily washed and concentrated and purified with the process of extraction. Then, 
the essence of the herbal extracts -KY88- was assembled. Also, this capsule had been verified by SGS Hong Kong Ltd (Socie'te' Ge'ne'rale de Surveillance) to be free of heavy metals and microorganisms. Before the study for inhibition ability, KY88 (50 g) was extracted with three times using $\mathrm{MeOH}$. The solid residue obtained from the crude extract was then dissolved in dimethyl sulphoxide to a concentration of $92 \mathrm{mg} / \mathrm{ml}$ and stored at $4^{\circ} \mathrm{C}$ until use (Loo et al. 2007).

\subsubsection{Effects of KY88 on cell proliferation and $\mathrm{HBeAg} / \mathrm{HBsAg}$ secretion}

Loo et al. (2007) was the first to investigate whether KY88 has an ability to inhibit hepatocellular carcinoma cell proliferation and the secretion ability of HBsAg (hepatitis B virus surface antigen) and HBeAg (hepatitis B virus core antigen). For this assessment, KY88 was applied to the HB-8064 hepatocellular carcinoma cell line, and the cell proliferation rate and $\mathrm{HBsAg} / \mathrm{HBeAg}$ secretion were measured on days 1, 3, 5 and 7. The MTT assay showed that the treatment of $0.1,0.5$ and $1 \mathrm{mg} / \mathrm{ml} \mathrm{KY} 88$ for 7 days induced the significant suppression of hepatic carcinoma. Additionally, the cell proliferation rate of all KY88treated cells was significantly lower than that of the control-treated group (Fig. 6). In particular, a remarkable suppression of cell proliferation was detected at three concentrations from day 5. Therefore, these data demonstrated that KY88 may potentially exert an effect in inhibiting the cellular proliferation of hepatocellular carcinoma.

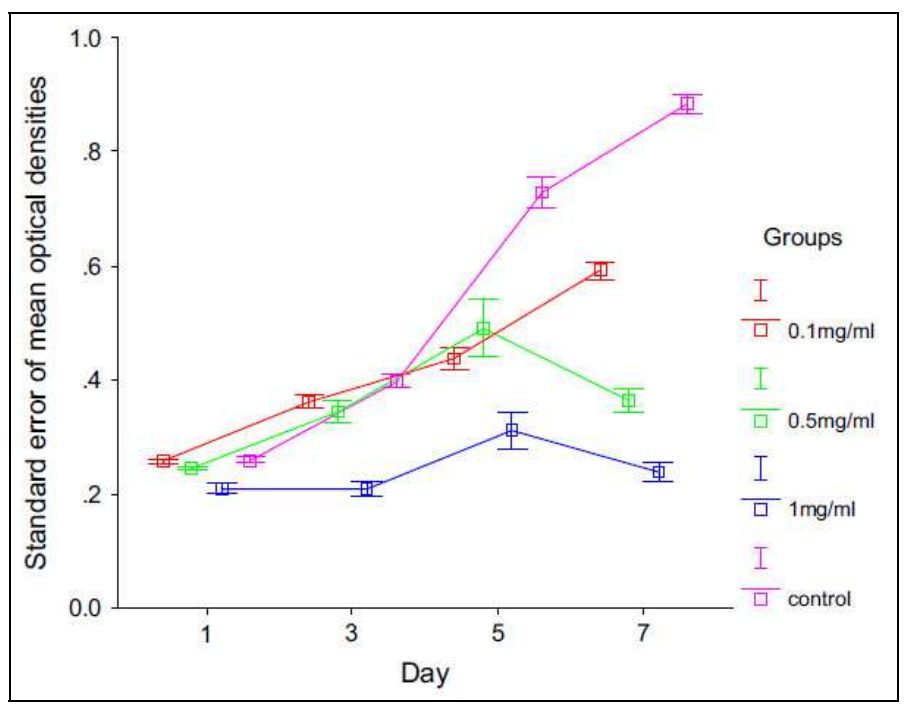

Fig. 6. Dose-dependent inhibition of cell proliferation at three concentrations of KY88 (Loo et al., 2007).

Furthermore, the secretions of HBsAg and HBeAg from the hepatocellular carcinoma cell line were dramatically inhibited by KY88 treatment (Fig. 7). The observation of HBsAg and $\mathrm{HBeAg}$ reflected the cell's infection with hepatitis B virus and their replication activity (Loo et al., 2007). This data indicated that KY88 may potentially have the ability to inhibit the proliferation of hepatocellular carcinoma cells, as well as the reduced secretions of HBsAg and HBeAg to restrict tumor growth. 

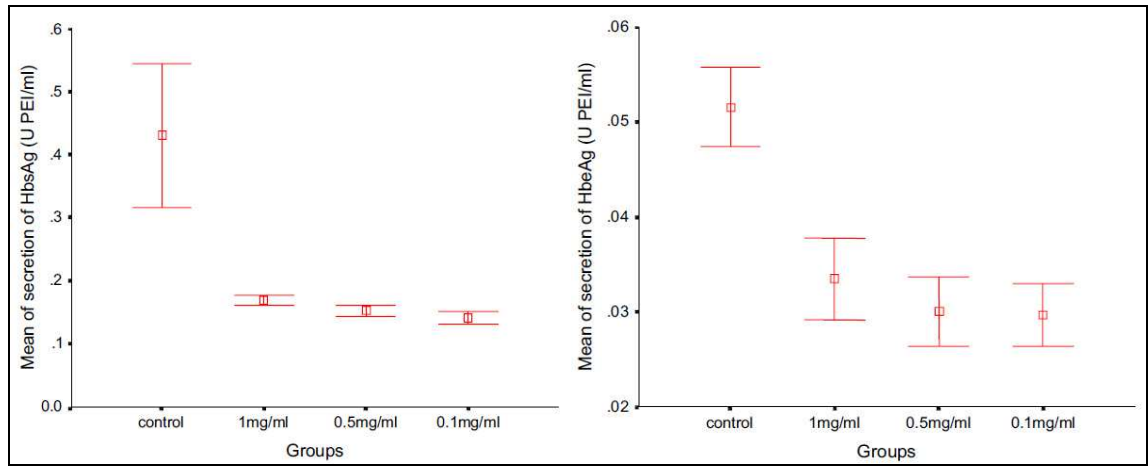

Fig. 7. Secretion level of HBsAg and HBeAg from hepatocellular carcinoma cell line after KY88 treatment (Loo et al., 2007).

\subsubsection{Effects of KY88 on apoptosis and cytokine secretion}

Chow et al. (2004) previously evaluated the effects and action mechanism of KY88 on liver cancer cells using methanol extracts of KY88 to develop a novel therapeutic drug for the treatment of hepatoma. After methanol extracts of KY88 were applied to a hepatocellular carcinoma cell line, the cell proliferation, DNA laddering and cytokine secretion were detected in these cells. KY88 induced a significant inhibition of cell proliferation and an increase in the DNA ladder pattern, which is a marker that indicates apoptosis in hepatocellular carcinoma cells (Fig. 8).

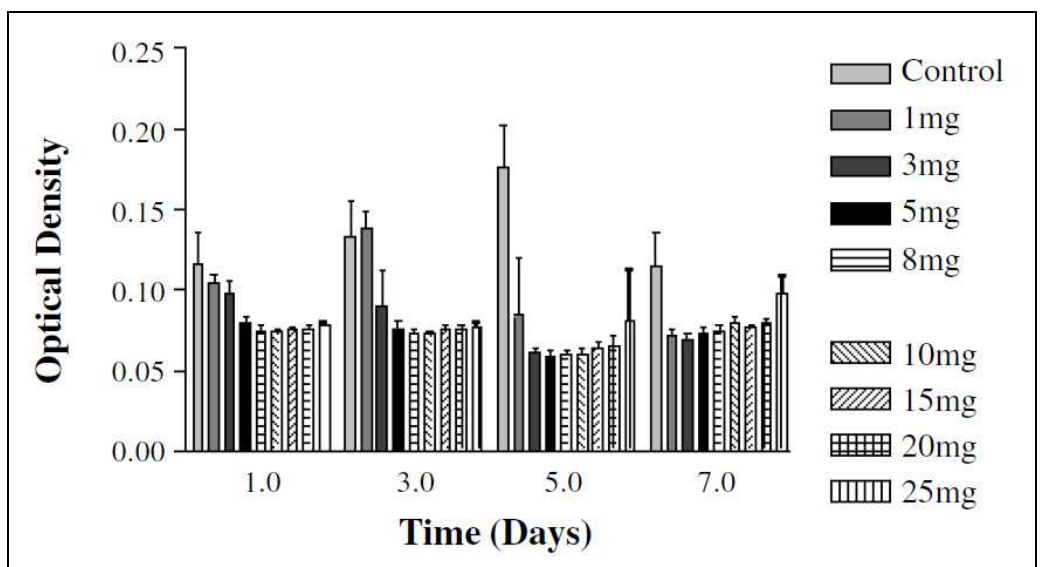

Fig. 8. Inhibition effect of KY88 methanol extracts on hepatocellular carcinoma cell (Chow et al., 2004).

Additionally, cytokine ELISA assay results demonstrated that IL-4 and TNF- $\alpha$ concentrations were increased significantly by KY88 treatment when compared against the control group at $24 \mathrm{hrs}$. However, IL-2, IL-6 and INF- $\gamma$ concentrations were maintained at constant levels (Fig. 9). Therefore, this data indicates that the methanol extracts of KY88 may induce apoptosis via the regulation of IL- 4 and TNF- $\alpha$ secretion. 


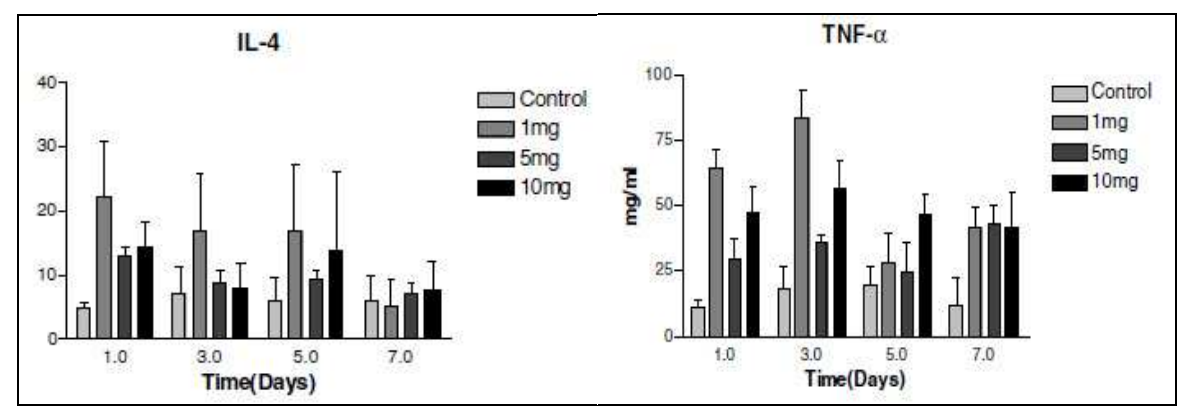

Fig. 9. Significant change of IL-4 and TNF- $\alpha$ level in hepatocellular carcinoma cell after KY88 treatment (Chow et al., 2004).

\subsection{Effects of schizandrin A}

Schizandrin A is referred to by several other names, including deoxyschizandrin, wuweizisu A, and deoxyschisandrin ( $\mathrm{Lu}$ and Chen, 2009), and is one of the most effective lignins isolated from S. chinensis (Fig. 10). Previous studies have also demonstrated that schizandrin A may have the hepatoprotective, antioxidative, neurobiological performance-improving and antitumor activities (Deng et al., 2008; Huang et al., 2008). For the first time, the function of schizandrin A was found to protect against liver injuries, activate liver regeneration and supress liver carcinogenesis (Zheng et al., 1997). Additionally, this lignan was partially used as a $\mathrm{Ca}^{2+}$ modulator which induced the synchronization of $\mathrm{Ca}^{2+}$ oscillation via the influx inhibition of extracellular $\mathrm{Ca}^{2+}$ and the initiation of action potential (Fu et al., 2008). However, only a small amount of research has been conducted regarding the possible inhibitory effects of schizandrin A on hepatocellular carcinoma. This chapter also describes recent key results regarding the possible anti-liver cancer effects of schizandrin A.

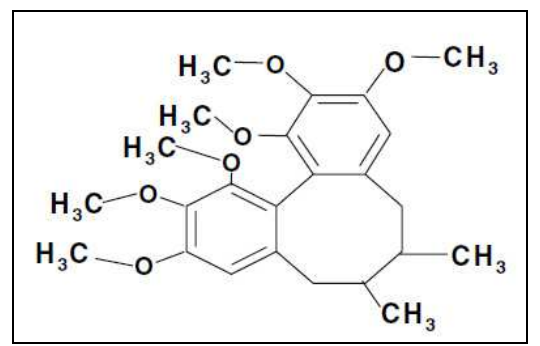

Fig. 10. Chemical structure of schizandrin A isolated from S. chinensis.

\subsubsection{Preparation of schizandrin A}

Generally, schizandrin A was prepared with a methods suggested by Chen et al. (1976) and Yue et al. (1994). Firstly, S. chinensis Baill $(10 \mathrm{~kg})$ was extracted with $50 \mathrm{~L}$ of hexane for $1.5 \mathrm{hr}$ and the obtained extract was dried under a reduced pressure. The $978.8 \mathrm{~g}$ of hexane extract were dissolved in $9.8 \mathrm{~L}$ of hexane and sequentially extracted two times with $9.8 \mathrm{~L}$ of $60 \% \mathrm{v} / \mathrm{v})$ $\mathrm{MeOH}$. The mixture obtained from above extraction was dried under a reduced pressure and finally $112.2 \mathrm{~g}$ of a fraction having a high lignan content were obtained. These fraction having a high lignan content was subjected to the fractionation high-speed liquid chromatography 
[column: Kiesel Gel 60 (230 to 400 mesh) supplied by Merk, diameter=10 cm, length=100 cm, moving phase: n-hexane/ethyl acetate (7/3), flow rate: $200 \mathrm{ml} / \mathrm{min}$, apparatus: Waters Prep LC/System 500A]. Fractions eluted at 63 to 70 minutes in the fractionation high-speed liquid chromatography were combined and dried under a reduced pressure. The obtained residue (schizandrin A) was recrystallized from methanol to obtain $1.05 \mathrm{~g}$ of a colorless prism crystal.

\subsubsection{Effects of schizandrin A and LCC (five schizandrins and crud extract from Fructus shizandrae) on human hepatocellular carcinoma}

Huang et al. (2008) evaluated the reversal effects of five schizandrins (schizandrin A, schizandrin B, schizandrin C, schizandrol A and schizandrol B) and LCC on multidrug resistance (MDR) in several cancer cells, including hepatocellular carcinoma and epidermal carcinoma in vitro and in vivo. After treatment with various concentrations of five schizandrins and LCC into cancer cell lines, drug sensitivity, apoptosis, doxorubicin (Dox) accumulation and protein kinas $\mathrm{C}$ (PKC) expression were measured in cancer cell lines. Various levels of MDR reversal activity were noted at a $25 \mu \mathrm{M}$ concentration of the five tested compounds. The most potent compound found was schizandrin A. The reversal activity of MDR was also induced by $25 \mu \mathrm{g} / \mathrm{ml}$ of LCC in KBV200, MCF-7/Dox cells, and human hepatic cellular carcinoma Bel7402 cells. The flow cytometry analysis results demonstrated that both schizandrin A and LCC treatment induced an increase in apoptosis in human hepatocellular carcinoma cells. As shown in Fig. 11, the sub-G1 peak, which is one of the characteristics of apoptosis, was increased significantly from $1.8 \%$ in the Bel7402 cells treated with Dox only to $10-14 \%$ in the schizandrin A + Dox-treated cells or the LCC + Dox-treated cells. Additionally, chromatin condensation, another marker of apoptosis, was enhanced in cells treated with schizandrin A + Dox or with LCC + Dox. Furthermore, downregulations of PKC and Pglycoprotein expression were noted in cells treated with schizandrin A + Dox or LCC + Dox (Fig. 11). These data showed that schizandrin A and LCC may induce a reversal of MDR in cancer cells via the inhibition of P-glycoprotein and PKC expression.

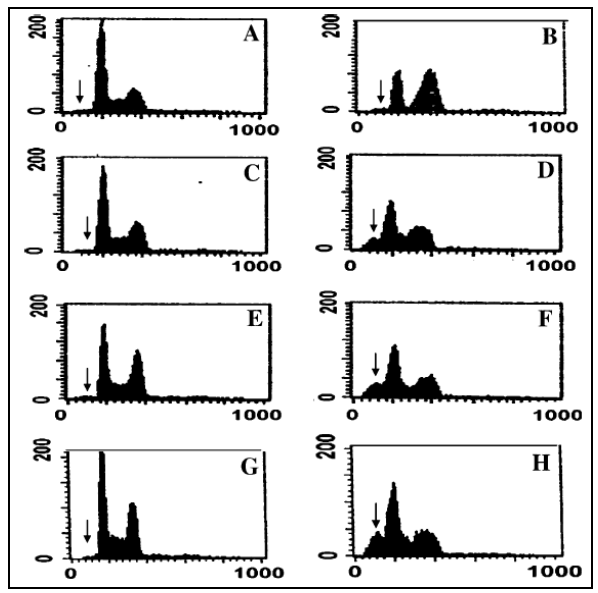

Fig. 11. Enhancing effects of schizandrin A and LCC on apoptosis in human hepatocellular carcinoma cells. A Control, B Dox 1,250 ng/ml, C Verapamil (VPL) $20 \mu$ M, D Dox 1,250 $\mathrm{ng} / \mathrm{ml}+\mathrm{VPL} 20 \mu \mathrm{M}$, E Schizandrin A $25 \mu \mathrm{M}, \mathbf{F}$ Dox 1,250 ng/ml + Schizandrin A $25 \mu \mathrm{M}, \mathrm{G}$ LCC $25 \mu \mathrm{g} / \mathrm{ml}$, H Dox 1,250 ng/ml + LCC $25 \mu \mathrm{g} / \mathrm{ml}$ (Huang et al., 2008). 


\subsubsection{Effects of LCC on the tumor growth of mice}

In order to confirm the MDR-reversing effects of LCC and schizandrin A detected in vitro, tumor growth was measured in nude mice bearing KBv200 xenografts. Following 10 days of vincristine injection, tumor growth was inhibited significantly-by approximately $12 \%$-when tumor size was compared to that of the control group (Huang et al., 2008). Furthermore, cotreatment with LCC and vincristine at 100, 200 and $300 \mathrm{mg} / \mathrm{kg} \mathrm{BW}$ increased the anti-tumor activity induced by vincristine in a dose-dependent manner (Fig. 12). In particular, LCC 300 $\mathrm{mg} / \mathrm{kg} \mathrm{BW}$ co-treatment for 15 days resulted in dramatic differences-most notably, a $41.9 \%$ inhibition of tumor size (Huang et al., 2008). These results indicate that LCC has potential for use in the development of a therapeutic drug for hepatoma in vivo.

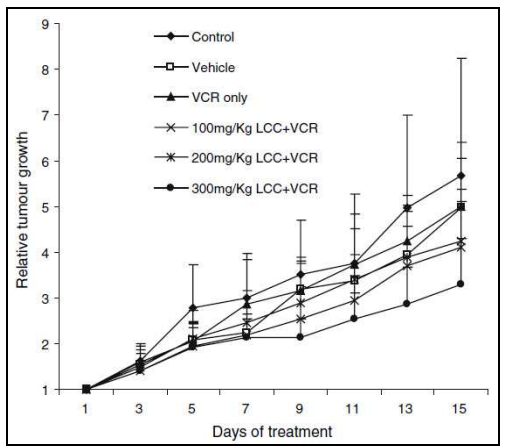

Fig. 12. Inhibition effects of LCC on vincristine-induced anti-tumor activity in nude mice bearing the KBv200 xenograft (Huang et al., 2008).

\subsection{Effects of TGH}

The structure of TGH (Fig. 13) was firstly assessed by Ikeya et al. (1978a). In Korea, this lignin was initially identified via gas chromatography/mass spectrometry (GC/MS) from $S$. chinensis harvested in Muju, Korea (Sohn and Bock, 1989). However, many things remain unknown regarding the functions of this lignan. Recently, several important study results suggesting a possible function of TGH in cancer therapy have caused an increase in interest in the compound.

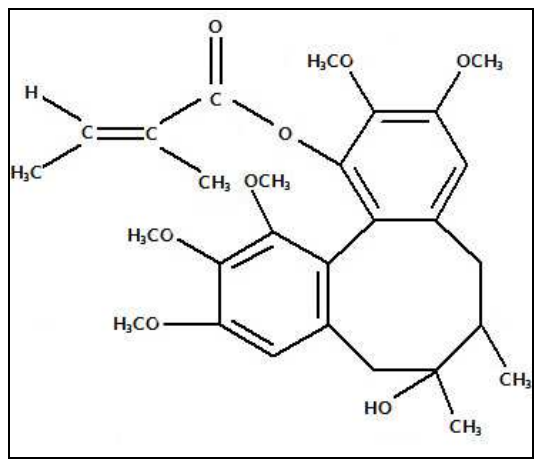

Fig. 13. Chemical structure of TGH isolated from S. chinensis. 


\subsubsection{Preparation of TGH}

In order to prepare $\mathrm{TGH}$, the fruit of $S$. chinensis ( $250 \mathrm{~g}$ ) was firstly extracted three times using $500 \mathrm{~mL}$ of $\mathrm{MeOH}$ with sonication for $1 \mathrm{hr}$. The dried $\mathrm{MeOH}$ extract was collected from filtered solution with dryness under reduced pressure. Then, $\mathrm{MeOH}$ extract $(50 \mathrm{~g})$ was suspended in water and sequentially fractionated with $n$-hexane and $\mathrm{CH}_{2} \mathrm{Cl}_{2}$. The purified $n$-hexane fraction (10 g) was subjected to chromatography on an RP-18 column $(4.5 \times 20 \mathrm{~cm}$, 5:5 - 9:1 MeOH:water, v/v) to yield fractions 1-8. Furthermore, fraction 4 (650 mg) was dissolved in $\mathrm{MeOH}$ and subjected to isocratic semi-preparative HPLC using an YMC Jsphere ODS column $(20 \times 250 \mathrm{~mm}, 4 \mu \mathrm{m}$; YMC). TGH was separated with MeCN-0.1\% TFA in $\mathrm{H} 2 \mathrm{O}$ ( $50: 50$ in $50 \mathrm{~min}, 10 \mathrm{~mL} / \mathrm{min}, 254 \mathrm{~nm}$ ) to yield $62.0 \mathrm{mg}$ of compound 4 (93.65\%). The identity of TGH was confirmed by 1H- and 13C-NMR spectroscopy (Lee et al., 2009).

\subsubsection{Effects of TGH on cell survival}

Lee et al. (2009) initially investigated the anti-cancer functions and action mechanisms of nine lignans isolated from the fruit of $S$. chinensis. Firstly, nine lignans including schisandrol A, schisandrol A, TGH, angeloylgomisin $\mathrm{H}(\mathrm{AGH})$, schisandrin A, schisandrin B, gomisin J, gomisin $\mathrm{N}$ and schisandrin $\mathrm{C}$ were isolated from $\mathrm{S}$. chinensis and the effects of each lignin on the cell survival rate were determined. Among the nine lignans, TGH induced a reduction in cell survival at concentrations ranging from $31.3 \mu \mathrm{M}$ to $250.0 \mu \mathrm{M}$, whereas the AGH samples maintained a steady level in terms of cell survival (Fig. 14). During this period, the quinone reductase activity was dramatically increased in hepatocarcinoma cells and evidenced a high chemoprevention index. Additionally, the mechanism study results demonstrated that the expression of genes mediated by the antioxidant response element (ARE), an important regulatory region in the promoter of the detoxification enzyme gene which is regulated by the nuclear accumulation of Nrf2, was enhanced significantly by TGH. Therefore, all study results appear to indicate that TGH may be considered as a potential liver cancer-preventive compound that specifically induces increases in antioxidant enzyme expression via the formation of the Nrf2-ARE binding complex.

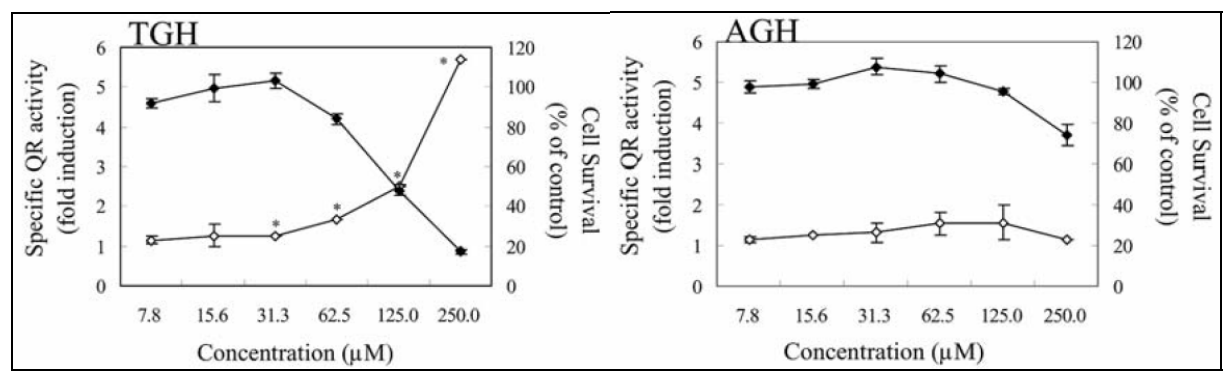

Fig. 14. Effects of TGH treatment on the quinone reductase activity and cell survival (Lee et al., 2009).

\section{Conclusion}

The development of novel therapeutic drugs for hepatic carcinoma is a very important objective in the field of pharmacological research. Among the variety of approaches thus far pursued to develop novel drugs, identification and screening of natural compounds from 
medical herbs has proven a very effective one-not least, because this method saves a great deal of time and cost. Recently, many institutes and companies in advanced countries have focused on an approach to novel drugs for hepatic carcinoma via the use of various lignins isolated from $S$. chinensis. This chapter introduces three lignans and one blend which may prove valuable in efforts to combat hepatic carcinoma. Gomisin A at high concentration was found to significantly induce anti-proliferative and pro-apoptotic effects in hepatic carcinoma. Schizandrin A markedly increased vincristine-induced hepatic carcinoma apoptosis and anti-tumor activity. Additionally, TGH induced the death of hepatic carcinoma cells and inhibited quinone reductase activity. Furthermore, KY88 was a blend composed of 10 herbal extracts and effects a dose-dependent inhibition of hepatocellular carcinoma cellular proliferation (Table 3).

Collectively, the results of these studies demonstrated that these lignins and the blend from S. chinensis were regarded as an anti-cancer drug candidate capable of inducing apoptosis and inhibiting the cell proliferation of hepatocellular carcinoma via a variety of mechanisms.

\begin{tabular}{|l|l|l|}
\hline Compounds & Function on hepatocellular carcinoma & References \\
\hline Gomisin N & $\begin{array}{l}\text { - Induction of hepatic carcinoma apoptosis } \\
\cdot \text { Increase of Bcl-2 protein expression }\end{array}$ & Yim et al., 2009 \\
\hline KY88 & $\begin{array}{l}\text {-Dose-dependent inhibition of hepatocellular } \\
\text { carcinoma proliferation and secretion of HBsAg and } \\
\text { HBeAg } \\
\text {-Induction of hepatic carcinoma apoptosis and IL- } \\
\text { 4/TNF- } \alpha \text { secretion }\end{array}$ & Loo et al., 2007 \\
\hline Schizandrin A & $\begin{array}{l}\text {-Induction of hepatic carcinoma apoptosis and PKC } \\
\text { down regulation } \\
\text {-Increase of anti-tumor activity induced by vincristine }\end{array}$ & Huang et al., 2008 \\
\hline TGH & $\begin{array}{l}\text {-Induction of hepatic carcinoma death and inhibition } \\
\text { of quinone reductase activity }\end{array}$ & Lee et al., 2009 \\
\hline
\end{tabular}

Table 3. Summary therapeutic function of three lignins and one blend from S. chinensis on hepatocellular carcinoma.

\section{Acknowledgments}

I would like to express my gratitude to students, including JE Kim, SH Nam, SI Choi, IS Hwang, HR Lee and YJ Lee in our laboratory, for helping to compile this paper and with the graphics and charts herein.

\section{References}

\section{Print Books}

Adami, HO; Hunter, D. \& Trichopoulos, D. (2008): Cancer of the Liver and Biliary Tract. In: Textbook of Cancer Epidemiology (Second edition), Oxford University Press, ISBN 9780-19-531117-4, Oxford England, pp. 308-332 
Agejenko, AS. \& Komissarenko, BT. (1960). Schizandra and its Therapeutic Administration. Sakhalinsk Book Press, Yuzhno-Sakhalinsk, p. 38

Gutnikova, ZI. (1951). Schizandra chinensis in the Far East. In: Lazarev,N.V. (Ed.), Materials for the Study of Ginseng and Schizandra Roots. Far East Branch of USSR Academy of Science, Vladivostok, pp. 23-43

Shilova, LM. (1963). On the problem of sexual dimorphism and pollination in Schizandra chinensis. In: Brekhman, I.I., Belikov, I.F., Kuznetsova, G.E. (Eds.), Materials for the Study of Ginseng and Schizandra. Far East Branch of the USSR Academy of Science, Primorsk Book Publisher, Vladivostok, pp. 267-270

\section{Papers in Journals}

Apakama, I.; Robinson, MC.; Walter, NM.; Charlton, RG.; Royds, JA.; Fuller, CE.; Neal, DE. \& Hamdy, FC. (1996) Bcl-2 overexpression combined with p53 accumulation correlates with hormone refractory prostate cancer. British Journal of cancer, Vol. 74, No. 8, (October 1996), pp. 1258-1262, ISSN 0007-0920

Bosch, FX.; Ribes, J.; Díaz, M. \& Cléries, R. (2004) Primary liver cancer: worldwide incidence and trends. Gastroenterology, Vol. 127, No. 5, (November 2004), pp. S5-S16, ISSN 0016-5085

Bruix, J. \& Sherman, M. (2005) Management of hepatocellular carcinoma. Hepatology, Vol. 42, No. 5, (November 2005), pp. 1208-1236, ISSN 1527-3350

Chen, CC.; Shen, CC.; Shih, YZ. \& Pan, TM. (1994) 6-O-Benzoylgomisin O, a New Lignan from the Fruits of Schizandra chinensis. Journal of Natural Products, Vol. 57, No. 8, (August 1994), pp. 1164-1165, ISSN 0163-3864

Chen, YY.; Shu, ZB. \& Li, LN. (1976) Studies of Fructus schizandrae. IV. Isolation and determination of the active compounds (in lowering high SGPT levels) of Schizandra chinensis Baill. Scientia Sinica, Vol. 19, No. 2, (April 1976), pp. 276-290, ISSN 0250-7870

Chiu, PY.; Leung, HY.; Poon, MK.; Mak, DH. \& Ko, KM. (2006) Effects of schisandrin B enantiomers on cellular glutathione and menadione toxicity in AML12 hepatocytes. Pharmacology, Vol. 77, No. 2, (April 2006), pp. 63-70, ISSN 0031-7012

Choi, YW.; Takamatsu, S.; Khan, SI.; Srinivas, PV.; Ferreira, D.; Zhao, J.P. \& Khan I.A. (2006) Schisandrene, a Dibenzocyclooctadiene Lignan from Schisandra chinensis: Structure-Antioxidant Activity Relationships of Dibenzocyclooctadiene Lignans. Journal of Natural Products, Vol. 69, No. 3, (December 2005), pp. 356-359, ISSN 01633864

Chow, CW.; Loo, TY.; Sham, ST. \& Cheung, NB. (2004) Radix bupleuri containing compound (KY88 liver-livo) induces apoptosis and production of interleukin-4 and tumor necrosis factor-alpha in liver cancer cells in vitro. The American Journal of Chinese Medicine, Vol. 32, No. 2, (February 2004), pp. 185-93, ISSN 0192-415X

Chow, LW.; Loo, WY. \& Sham, JS. (2001) Effects of a herbal compound containing bupleurum on human lymphocytes. Hong Kong Medical Journal, Vol. 7, No. 4, (December 2001), pp. 408-413, ISSN 1024-2708

Deng, X.; Chen, X.; Yin, R.; Shen, Z.; Qiao, L. \& Bi, K. (2008) Determination of deoxyschizandrin in rat plasma by LC-MS. Journal of Pharmaceutical Biomedical Analysis, Vol. 46, No. 1, (January 2008), pp. 121-126, ISSN 0731-7085 
El-Serang, HB. \& Mason, AC. (2000) Risk factors for the rising rates of primary liver cancer in the United States. Archives of Internal Medicine, Vol. 160, No. 21, (November 2000), pp. 3227-3230, ISSN 0003-9926

Fu, M.; Sun, ZH.; Zong, M.; He, XP.; Zuo, HC. \& Xie, ZP. (2008) Deoxyschisandrin modulates synchronized Ca2+ oscillations and spontaneous synaptic transmission of cultured hippocampal neurons. Acta Pharmacologica Sinica, Vol. 29, No. 8, (August 2008), pp. 891-898, ISSN 1671-4083

Huang, M.; Jin, J.; Sun, H. \& Liu, GT. (2008) Reversal of P-glycoprotein-mediated multidrug resistance of cancer cells by five schizandrins isolated from the Chinese herb Fructus Schizandrae. Cancer Chemotherapy and Pharmacology, Vol. 62, No. 6, (November 2008), pp. 1015-1026, ISSN 0344-5704

Ikeya, Y.; Kanatani, H.; Hakozaki, M.; Taguchi, H. \& Mitsuhashi, H. (1988) The constituents of Schizandra chinensis Baill. XV. Isolation and structure determination of two new lignans, gomisin S and gomisin T. Chemical \& Pharmaceutical Bulletin, Vol. 36, No. 10, (October 1988), pp. 3974-3979, ISSN 0009-2363

Ikeya, Y.; Miki, E.; Okada, M.; Mitsuhashi, H. \& Chai, JG. (1990) Benzoylgomisin Q and benzoylgomisin $\mathrm{P}$, two new lignans from Schisandra sphenanthera Rehd. et Wils. Chemical \& Pharmaceutical Bulletin, Vol. 38, No. 5, (May 1990), pp. 1408-1411, ISSN 0009-2363

Ikeya, Y.; Ookawa, N.; Taguchi, H. \& Yosioka, I. (1982b) The constituents of Schizandra chinensis Baill. XI. The structures of three new lignans, angeloylgomisin $\mathrm{O}$, and angeloyl- and benzoylisogomisin O. Chemical \& Pharmaceutical Bulletin, Vol. 30, No. 9, (September 1982b), pp. 3202-3206, ISSN 0009-2363

Ikeya, Y.; Sugama, K.; Okada, M. \& Mitsuhashi, H. (1991) Two lignans from Schisandra sphenanthera. Phytochemistry, Vol. 30, No. 3, (March 1991), pp. 975-980, ISSN 00319942

Ikeya, Y.; Taguchi, H. \& Litaka, Y. (1976) The constituents of Schizandra chinensis Baill. The structure of a new lignin, gomisin D. Tetrahedron Letters, Vol. 17, No. 17, (April 1976), pp. 1359-1362, ISSN 0040-4039

Ikeya, Y.; Taguchi, H. \& Yosioka, I. (1979d) The constituents of Schizandra chinensis Baill. The cleavage of the methylenedioxy moiety with lead tetraacetate in benzene, and the structure of angeloylgomisin Q. Chemical \& Pharmaceutical Bulletin, Vol. 27, No. 10, (October 1979d) pp. 2536-2538, ISSN 0009-2363

IKeya, Y.; Taguchi, H. \& Yosioka, I. (1980a) The constituents of Schizandra chinensis Baill. VII. The structures of three new lignans, (-)-gomisin K1 and (+)-gomisins K2 and K3. Chemical \& pharmaceutical bulletin, Vol. 28, No. 8, (August 1980a), pp. 2422-2427, ISSN 0009-2363

IKeya, Y.; Taguchi, H. \& Yosioka, I. (1982a) The constituents of Schizandra chinensis BAILL. $X$. The structures of $\gamma$-schizandrin and four new lignans, (-)-gomisins L1 and L2, $( \pm)$-gomisin M1 and (+)-gomisin M2. Chemical \& pharmaceutical bulletin, Vol. 30, No. 1, (January 1982a), pp. 132-139, ISSN 0009-2363

Ikeya, Y.; Taguchi, H. \& Yosioka, I. (1982c) The Constituents of Schizandra chinensis BAILL. XII. Isolation and Structure of a New Lignan, Gomisin R, the Absolute Structure of Wuweizisu C and Isolation of Schisantherin D. Chemical \& Pharmaceutical Bulletin, Vol. 30, No. 9, (September 1982c) pp. 3207-3211, ISSN 0009-2363 
Ikeya, Y.; Taguchi, H.; Yosioka, I. \& Kobayashi, H. (1978a) The constituents of Schizandra chinensis BAILL. The structures of two new lignans, pre-gomisin and gomisin J. Chemical \& Pharmaceutical Bulletin, Vol. 26, No. 2, (February 1978a), pp. 682-684, ISSN 0009-2363

Ikeya, Y.; Taguchi, H.; Yosioka, I. \& Kobayashi, H. (1978b) The Constituents of Schizandra chinensis BAILL. The Structures of Two New Lignans, Gomisin N and Tigloylgomisin P. Chemical \& pharmaceutical bulletin, Vol. 26, No. 10, (October 1978b), pp. 3257-3260, ISSN 0009-2363

Ikeya, Y.; Taguchi, H.; Yosioka, I. \& Kobayashi, H. (1979a) The constituents of Schizandra chinensis Baill. I. Isolation and structure determination of five new lignans, gomisin A, B, C, F and G, and the absolute structure of schizandrin. Chemical $\mathcal{E}$ pharmaceutical bulletin, Vol. 27, No.6, (November 1979a), pp. 1383-1394, ISSN 00092363

Ikeya, Y.; Taguchi, H.; Yosioka, I. \& Kobayashi, H. (1979b) The constituents of Schizandra chinensis Baill. III. The structures of four new lignans, gomisin $\mathrm{H}$ and its derivatives, angeloyl-, tigloyl- and benzoyl-gomisin H. Chemical $\mathcal{E}$ pharmaceutical bulletin, Vol. 27, No. 7, (July 1979b), pp. 1576-1582, ISSN 0009-2363

Ikeya, Y.; Taguchi, H.; Yosioka, I. \& Kobayashi, H. (1979c) The constituents of Schizandra chinensis Baill. IV. The structures of two new lignans, pre-gomisin and gomisin J. Chemical \& Pharmaceutical Bulletin, Vol. 27, No. 7, (July 1979c) pp. 1583-1588, ISSN 0009-2363

Ikeya, Y.; Taguchi, H.; Yosioka, I. \& Kobayashi, H. (1979e) The constituents of Schizandra chinensis Baill. V. The structures of four new lignans, gomisin $\mathrm{N}$, gomisin $\mathrm{O}$, epigomisin $\mathrm{O}$ and gomisin $\mathrm{E}$, and transformation of gomisin $\mathrm{N}$ to deangeloylgomisin B. Chemical \& Pharmaceutical Bulletin, Vol. 27, No. 11, (December 1979e), pp. 2695-2709, ISSN 0009-2363

Ikeya, Y.; Taguchi, H.; Yosioka, I.; Yosioka, I. \& Kobayashi, H. (1980b) The constituents of Schizandra chinensis Baill. VIII. The structures of two new lignans,tigloylgomisin P and angeloylgomisin P. Chemical \& Pharmaceutical Bulletin, Vol. 28, No. 11, (November 1980b), pp. 3357-3361, ISSN 0009-2363

Joensuu, H.; Pylkkänen, L. \& Toikkanen, S. (1994) Bcl-2 protein expression and long-term survival in breast cancer. The American Journal of pathology, Vol. 145, No. 5, (May 1994), pp. 1191-1198, ISSN 0002-9440

Ko, KM. \& Lam, BY. (2002) Schisandrin B protects against tert-butylhydroperoxide induced cerebral toxicity by enhancing glutathione antioxidant status in mouse brain. Molecular E Cellular Biochemistry, Vol. 238, No. 1-2, (September 2002), pp. 181-186, ISSN 0300-8177

Lee, SB.; Kim, CY.; Lee, HJ.; Yun, JH. \& Nho, CW. (2009) Induction of the phase II detoxification enzyme NQO1 in hepatocarcinoma cells by lignans from the fruit of Schisandra chinensis through nuclear accumulation of Nrf2. Planta Medica, Vol. 75, No. 12, (October 2009), pp. 1314-1318

Liu, CS.; Fang, SD.; Huang, MF.; Kao, YL. \& Hsu JS. (1978) Studies on the active principles of Schisandra sphenanthera Rehd. et Wils. The structures of schisantherin A, B, C, D, E, and the related compounds. Scientia Sinica, Vol. 21, No. 4, (July-August 1978), pp. 483-502, ISSN 0250-7870 
Loo, WT.; Cheung, MN. \& Chow, LW. (2007) Fructus schisandrae (Wuweizi)-containing compound inhibits secretion of HBsAg and HBeAg in hepatocellular carcinoma cell line. Biomedicine \& Pharmacotherapy, Vol. 61, No. 9, (October 2007), pp. 606-610, ISSN 0753-3322

Lu, Y. \& Chen, DF. (2009) Analysis of Schisandra chinensis and Schisandra sphenanthera. Journal of Chromatography A, Vo. 1216, No. 11, (March 2009), pp. 1980-1990, ISSN 0021-9673

Panossian, A. \& Wikman, G. (2008) Pharmacology of Schisandra chinensis Bail.: an overview of Russian research and uses in medicine. Journal of Ethnopharmacology, Vol. 118, No. 2, (July 2008), pp. 183-212, ISSN 0378-8741

Park, JY.; Lee, SJ.; Yun, MR.; Seo, KW.; Bae, SS.; Park, JW.; Lee, YJ.; Shin, WJ.; Choi, YW. \& Kim, CD. (2007) Gomisin A from Schisandra chinensis induces endotheliumdependent and direct relaxation in rat thoracic aorta. Planta Medica, Vol. 73, No. 15, (December 2007), pp. 1537-1542, ISSN 0032-0943

Sakurai, H.; Nikaido, T.; Ohmoto, T.; Ikeya, Y. \& Mitsuhashi, H. (1992) Inhibitors of adenosine 3',5'-cyclic monophosphate phosphodiesterase from Schisandra chinensis and the structure activity relationship of lignans. Chemical $\mathcal{E}$ Pharmaceutical Bulletin, Vol. 40, No. 5, (May 1992), pp. 1191-1195, ISSN 0009-2363

Seo, SM.; Lee, HJ.; Park, YK.; Lee, MK.; Park, JI.; Paik, KH. \& Park, JI. (2004). Lignans from the fruits of Schizandra chinensis and their inhibitory effects on dopamine content in PC12 cells. Natural Product Sciences, Vol.10, No.3, (June 2004), pp. 104-108, ISSN 1226-3907

Sohn, HJ. \& Bock, JY. (1989) Identification of lignan compounds in fruits of Schizandra chinensis BAILLON by gas chromatography/mass spectrometry. Journal of the Korean Agricultural Chemical Society, Vol. 32, No. 4, (December 1989), pp. 344-349, ISSN 0368-2897

Taguchi, H. \& Ikeya, Y. (1977) The Constituents of Schizandra chinensis BAILL. The Structures of Two New Lignans, Gomisin F and G, and the Absolute Structures of Gomisin A, B, and C. Chemical \& Pharmaceutical Bulletin, Vol. 25, No. 2, (February 1977), pp. 364-366, ISSN 0009-2363

Thomas, MB. \& Zhu, AX. (2005) Hepatocellular carcinoma: the need for progress. Journal of Clinical Oncology, Vol. 23, No. 13, (May 2005), pp. 2892-2829, ISSN 0732-183X

Yim, SY.; Lee, YJ.; Lee, YK.; Jung, SE.; Kim, JH.; Kim, HJ.; Son, BG.; Park, YH.; Lee, YG.; Choi, YW. \& Hwang, DY. (2009) Gomisin N isolated from Schisandra chinensis significantly induces anti-proliferative and pro-apoptotic effects in hepatic carcinoma. Molecular medicine reports, Vol. 2, No. 5, (October 2009), pp. 725-732, ISSN 1791-2997

Yue, JM.; Jun, X. \& Chen, YZ. (1994) Triterpenoids of Schisandra sphenanthera. Phytochemistry, Vol. 35, No. 4, (April 1994), pp. 1068-1069, ISSN 0031-9422

Zheng, RL.; Kang, JH.; Chen, FY.; Wang, PF.; Ren, JG. \& Liu, QL. (1997) Difference in antioxidation for schisandrins and schisantherin between bio- and chemo-systems. Phytotherapy Research, Vol. 11, No. 8, (December 1997), pp. 600-602, ISSN 1099-1573 


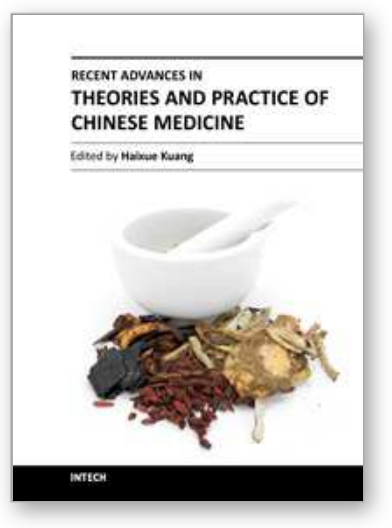

\author{
Recent Advances in Theories and Practice of Chinese Medicine \\ Edited by Prof. Haixue Kuang
}

ISBN 978-953-307-903-5

Hard cover, 504 pages

Publisher InTech

Published online 18, January, 2012

Published in print edition January, 2012

During the recent years, traditional Chinese medicine (TCM) has attracted the attention of researchers all over the world. It is looked upon not only as a bright pearl, but also a treasure house of ancient Chinese culture. Nowadays, TCM has become a subject area with high potential and the possibility for original innovation. This book titled Recent Advances in Theories and Practice of Chinese Medicine provides an authoritative and cutting-edge insight into TCM research, including its basic theories, diagnostic approach, current clinical applications, latest advances, and more. It discusses many often neglected important issues, such as the theory of TCM property, and how to carry out TCM research in the direction of TCM property theory using modern scientific technology. The authors of this book comprise an international group of recognized researchers who possess abundant clinical knowledge and research background due to their years of practicing TCM. Hopefully, this book will help our readers gain a deeper understanding of the unique characteristics of Chinese medicine.

\title{
How to reference
}

In order to correctly reference this scholarly work, feel free to copy and paste the following:

Dae Youn Hwang (2012). Therapeutic Effects of Lignans and Blend Isolated from Schisandra chinesis on Hepatic Carcinoma, Recent Advances in Theories and Practice of Chinese Medicine, Prof. Haixue Kuang (Ed.), ISBN: 978-953-307-903-5, InTech, Available from: http://www.intechopen.com/books/recent-advancesin-theories-and-practice-of-chinese-medicine/therapeutic-effects-of-lignans-and-blend-isolated-fromschisandra-chinesis-on-hepatic-carcinoma

\section{INTECH}

open science | open minds

\section{InTech Europe}

University Campus STeP Ri

Slavka Krautzeka 83/A

51000 Rijeka, Croatia

Phone: +385 (51) 770447

Fax: +385 (51) 686166

www.intechopen.com

\section{InTech China}

Unit 405, Office Block, Hotel Equatorial Shanghai

No.65, Yan An Road (West), Shanghai, 200040, China 中国上海市延安西路65号上海国际贵都大饭店办公楼 405 单元

Phone: +86-21-62489820

Fax: +86-21-62489821 
(C) 2012 The Author(s). Licensee IntechOpen. This is an open access article distributed under the terms of the Creative Commons Attribution 3.0 License, which permits unrestricted use, distribution, and reproduction in any medium, provided the original work is properly cited. 